\title{
Effet of Chlordecone on Rat Brain Parts Cnos Activity Livels in Vivo
}

\author{
B. Hemavathi ${ }^{1}$, M.R.Rao ${ }^{2}$, K.V.Kumari ${ }^{3}$, P.S.Poornima ${ }^{4}$ \\ ${ }^{1}$ Lecturer in Zoology, Ramaraja College of Education, Tirupati, Chittoor District, Andhra Pradesh, \\ ${ }^{2}$ Professor, Department of Zoology, S.V.University, Tirupati. Chittoor District, Andhra Pradesh. \\ ${ }^{3}$ Professor, Department of Zoology, S.V.University, Tirupati. Chittoor District, Andhra pradesh. \\ ${ }^{4}$ Lecturer in Zoology, S.V.Arts College Tirupati, Chittoor District, Andhra Pradesh.
}

\begin{abstract}
In view of the neurotoxic effects induced by chlordecone an attempt is made to study the in vivo effect of this organic insecticide on rat brain based nitric oxide synthase (NOS) activity. Rats cerebellum, hypothalamus, midbrain, straiatum, hippocampus, cerebral cortex and medulla oblongate receiving sub-lethal and lethal doses of chlordecone showed decreased levels of their constitutive NOS activity and the changes were found to be statistically significant ( $p<0.001)$ over the control. Since cNOS activity in dependent on calcium / calmodulin, interaction of chlordecone with $\mathrm{Ca}^{2+} \mathrm{CaM}$ mediated events might be the reason for inhibition of cNOS activity of various brain parts of rats.
\end{abstract}

\section{Introduction:}

In the years which followed natural was good, and concern was voiced from some quarters that the potential risks of pesticides out-weighed the benefits. This view has not diminished, but has been tempered in recent years with the emergence of other concerns allied to food production, and the realization that food like life is not risk free.Developing countries, whilst still farming over $54 \%$ of the available land, consume scarcely one-fifth of the global amount spent world wide for pesticides (McDougall, 1994).

It is recognized, however, that international trade of agriculture produce is a mojor increasing factor of pesticide usage mainly due to phytosanitary and plant quarantine requirements. Approximate pesticide consumption rates by refions is estimated as follows (Waibel, 1994): East Asia, including China, 38 percent; Latin America, 30; near East and North Africa, 15; South Asia, 13 and Africa South of Sahara, 4 percent. It is worthwhile comparing these apparently high inputs with the United States pesticide purchases in 1995 which accounted for $30 \%$ of the U.S. \$ 37.7 billion world market for the particular year (Anonymous, 1997).

\section{Materials And Methods:}

Albino rats of the weight range $150 \pm 5 \mathrm{~g}$ were used for the present study. Rats were maintained at constant temperature of $25^{\circ} \mathrm{C} \pm 5{ }^{\circ} \mathrm{C}$, humidity $60-70 \%$ they were fed with ad libitum commercial diet supplied by Sri Kamadhenu Agencies, Bangalore, India. 24 hrs prior to experiment they were tested with free access to water. They were fasted with free access to water. Theywere divided into groups of 10 each, maintained in separate cages and were used either for LD50 study or chlordecone treatment. For sub-lethal and lethal does of chlordecone treatment the numbers of rats used were seven ech for every treatment.

After determination of $\mathrm{LD}_{50}$ dose of chlordecone to rat per 48 hours, a rat colony was divided into three groups of seven each. I group acted as control one, the II group was gavaged with a sub-lethal chlordecone dose of $29.71 \mathrm{mg} / \mathrm{kg}$ and the III with a lethal dose chlordecone of $89.13 \mathrm{mg} / \mathrm{kg}$. after $48 \mathrm{hrs}$ chlordecone treatment of rats, the control and experimentalgroup of rats individually were anaesthetized with Katamine $(7 \mathrm{mg} / \mathrm{Kg})$.

From the whole brains dissected, the various brain parts like cerebellum, hypothalamus, midbrain, striatum, hippocampus, cerebral cortex and medulla oblongate were separated and individually frozen in liquid nitrogen and were stored at $-80^{\circ} \mathrm{C}$ till used.

\section{METHODS}

\section{NO Synthase assay (cNOS)}

Crude NOS preparation

The control and experimental brain parts were separately homogenized in ice-cold homogenizing buffer, containing $0.32 \mathrm{M}$ sucrose, $0.5 \mathrm{mM}$ HEPES, $\mathrm{pH} 7.2$ and $1 \mathrm{mM}$ dithiothreitol and were centrifuged at $1,00,000 \mathrm{~g}$ for $30 \mathrm{~min}$. The supernatants individually were passed over Dowex $\mathrm{Na}^{+}$form to remove endogenous arginine and the effluent was used for NOS assays.

Protein content was determined using Biorad protein assay kit and gamma globulin was used as standard. 


\section{NO synthase assay}

NOS activity in control and experimental samples was determined by enzymatic convertion of $\left[{ }^{3} \mathrm{H}\right]-$ arginine to $\left[{ }^{3} \mathrm{H}\right]$-citrulline as described by Bredt and Snyder (1989). Briefly, the samples were added to $400 \mathrm{Fl}$ of reaction mixture, containing $20 \mathrm{mM}$ HEPES, $\mathrm{pH} 7.2,2 \mathrm{mM} \mathrm{NADPH}, 0.05 \mathrm{mM} \mathrm{Ca}^{2+}, 6 \mathrm{FM} \mathrm{L}$-arginine, $2 \mathrm{~F}$ $\mathrm{Ci} / \mathrm{ml} \mathrm{L}-\left[2,3-{ }^{3} \mathrm{H}\right]$ arginine and different concentrations of pesticide solutions $(10-200 \mu \mathrm{M})$. After incubation for $45 \mathrm{~min}$ of $37^{\circ} \mathrm{C}$, the reaction was stopped by addition of $20 \mathrm{mM}$ HEPES, $10 \mathrm{mM}$ EGTA, pH 5.5. and was passed through Dowex AG $50 \mathrm{wx}-8\left(\mathrm{Na}^{+}\right.$form) column. NOS activity was quantified by measuring the radioactivity of the flow - through fractions containing $\left[{ }^{3} \mathrm{H}\right]$ - citrulline. The cNOS activity levels were expressed as P mol citrulline / $\mathrm{mg}$ protein / min.

TABLE - 1: Effect of sub-lethal and lethal doses of Chlordecone on cNOS activity levels in various parts of rat brain in vivo.

(Values expressed as P mol citrulline / $\mathrm{mg}$ protein / min)

\begin{tabular}{|c|c|c|c|}
\hline Name of the Brain part & Control & Sub-lethal Experimental & Lethal Experimental \\
\hline $\begin{array}{c}\text { Cerebellum } \\
\text { SD } \\
\text { PC } \\
\mathrm{t}\end{array}$ & $\begin{array}{c}50.23 \\
" 0.961\end{array}$ & $\begin{array}{c}45.09 \\
" 0.921 \\
-10.23 \\
P<0.001\end{array}$ & $\begin{array}{c}30.51 \\
" 0.912 \\
-39.25 \\
P<0.001\end{array}$ \\
\hline $\begin{array}{c}\text { Hypothalamus } \\
\text { SD } \\
\text { PC } \\
\text { t }\end{array}$ & $\begin{array}{l}42.08 \\
" 1.36\end{array}$ & $\begin{array}{c}31.12 \\
" 0.611 \\
-26.04 \\
P<0.001\end{array}$ & $\begin{array}{c}29.32 \\
" 1.21 \\
-30.32 \\
P<0.001\end{array}$ \\
\hline $\begin{array}{c}\text { Mid brain } \\
\text { SD } \\
\text { PC } \\
\text { t }\end{array}$ & $\begin{array}{c}38.91 \\
" 0.652\end{array}$ & $\begin{array}{c}29.44 \\
" 0.910 \\
-24.33 \\
P<0.001\end{array}$ & $\begin{array}{c}23.41 \\
" 0.910 \\
-39.83 \\
\mathrm{P}<0.001\end{array}$ \\
\hline $\begin{array}{l}\text { Striatum } \\
\text { SD } \\
\text { PC } \\
\mathrm{t}\end{array}$ & $\begin{array}{c}24.06 \\
" 0.491\end{array}$ & $\begin{array}{c}16.62 \\
" 0.212 \\
-30.92 \\
P<0.001\end{array}$ & $\begin{array}{c}14.02 \\
" 0.632 \\
-41.72 \\
P<0.001\end{array}$ \\
\hline $\begin{array}{c}\text { Hippocampus } \\
\text { SD } \\
\text { PC } \\
\text { t }\end{array}$ & $\begin{array}{c}23.79 \\
" 0.832\end{array}$ & $\begin{array}{c}16.91 \\
" 0.113 \\
-28.91 \\
P<0.001\end{array}$ & $\begin{array}{c}13.15 \\
" 0.420 \\
-44.72 \\
P<0.001\end{array}$ \\
\hline $\begin{array}{c}\text { Cerebral cortex } \\
\text { SD } \\
\text { PC } \\
\text { t }\end{array}$ & $\begin{array}{c}17.02 \\
" 0.089\end{array}$ & $\begin{array}{c}13.37 \\
" 0.441 \\
-21.44 \\
P<0.001\end{array}$ & $\begin{array}{c}9.60 \\
" 0.521 \\
-43.59 \\
P<0.001\end{array}$ \\
\hline $\begin{array}{c}\text { Medulla oblongata } \\
\text { SD } \\
\text { PC } \\
\text { t }\end{array}$ & $\begin{array}{c}15.50 \\
" 0.410\end{array}$ & $\begin{array}{c}13.16 \\
" 0.342 \\
-15.09 \\
P<0.001\end{array}$ & $\begin{array}{c}10.99 \\
" 0.411 \\
-29.09 \\
P<0.001\end{array}$ \\
\hline
\end{tabular}

Each value is the mean " SD of 7 samples

SD : $\quad$ Standard deviation

PC : Percent change over control ones.

Fig.1: Pecent change of sub-lethal and lethal doses of chlordecone on cNOS activity levels in various parts of rat brain in vivo

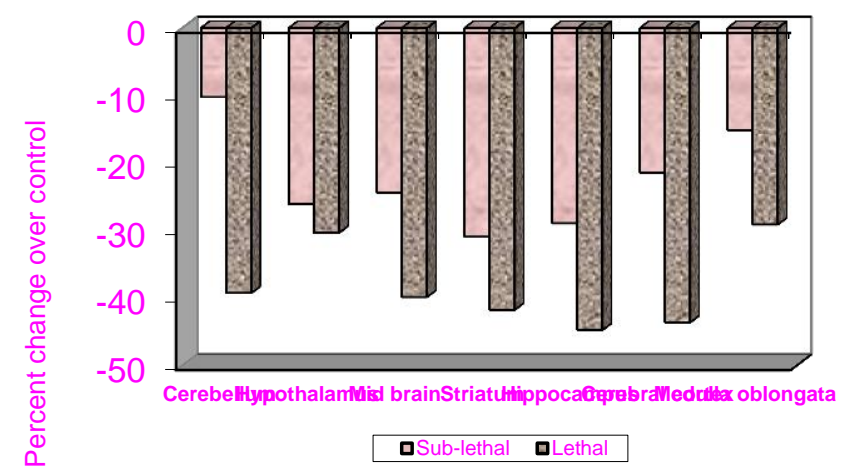




\section{Results}

In control and chlordecone treated rat brain parts the cNOS activity levels were measured and the data was presented in table-1. The sub-lethal and lethal doses of chlordecone depleted the brain parts soluble fraction cNOS activity and all the changes observed were found to be statistically significant $(\mathrm{P}<0.001)$ over the control. Amongst various brain parts studied, the cNOS activity of control rat cerebellum was more and was followed by hypothalamus > midbrain > striatum > hippocampus > cerebral cortex > medulla oblongata. The percent decrease in cNOS activity was more for brain regions receiving lethal dose of chlordecone (fig-1).

\section{Discussion}

The L-arginine NO pathway was originally identified in vascular endothelial cells and has been shown to occur in many other cell types. Although no systemic study has been carried out to identity its functional location in different tissues in the body. There are at least two distinct types of NO synthases (NOS : provisionally EC 1.14.13.39); a $\mathrm{Ca}^{2+}$ - dependent enzyme that has been shown to be present in the brain, vascular endothelium, vascular plate let and a $\mathrm{Ca}^{2+}$ - independent enzyme expressed in macrophages, liver cells, neutrophils, endothelial cells etc. (Salter et al., 1991).

The tissue distribution of cNOS has been characterized in rat brain and other tissues using polyclonal antibodies raised against the rat cerebellar enzyme (Bredt et al., 1990). There was a striking localization of NOS in rat cerebellum (glomeruli, granule cells, and basket cells ) and olfactory bulb, along with the islands of Callejea, diagonal bands of Broca, and the mammaliary nuclei. Other sites included neuronal projections in to the posterior lobe of the pituitary and adrenal medulla, and several autonomic nerves that contract smooth muscle. The antibodies also localized NOS in brain capillary endothelium, consistent with the view that a single cNOS isoform acconts for the activity of the neurons and vasculature. Conversely, the antibodies did not react with the inducible macrophage NOS, a finding indicating that this isoform is distinct from the constitutive enzyme. By direct assay of cytosolic fractions of rat brain, the cNOS activity was highest in cerebellum and decreased in the order hypothalamus $\cdot$ midbrain $>$ striatum - hippocampus - cerebral cortex $>$ medulla oblongata (Fostermann et al., 1990).

Endogenous inhibitors of NOS, such as methyl arginines, have been suggested to exist and, recently, it was reported that there is a $10 \mathrm{KDa}$ protein, named 'PIN' that is able to destabilize nNOS dimers, and hence inhibit enzyme activity in vitro (Jaffrey and Snyder, 1996). Many of the available synthetic NOS inhibitors are analogues of the substrate, $\mathrm{L}$-arginine, which act by competing with $\mathrm{L}$-arginine at the active site of the NOS. These inhibitors generally demonstrate little selectivity between three NOS isoforms and have the potential to interfere with other enzymes that utilize L-arginine, and affect its uptake into cells. The most widely used of these are $\mathrm{N}^{\mathrm{G}}$-monomethyl-L-arginine (L-NMMA), NG-nitro-L-arginine (L-NOARG) and $\mathrm{N}^{\mathrm{G}}$ nitro-L-arginine methylester (Griffiths et al., 1998; Connor 2002; Kolan Czyx - 2008; Oberg, 2010; Rauto,2012; Chighizola, 2012; Patisaul, 2013).

Aminoguanidine has traditionally been used to inhibit iNOS selectively, but it also reduced eNOS and nNOS activity. Recently, the compound N-(3-(aminomethyl) benzyl) acetamidine has been shown to be a potent and selective inhibitor of iNOS in vitro and in vivo. (Garvey et al., 1997). The compound 7nitroimidazole is a non-selective inhibitors of nNOS and eNOS in vitro. It acts by reducing the affinity of the enzymes for tetrahydrobiopterin and L-arginine. (Klatt et al., 1994). It is claimed to have some selectivity for nNOS in vivo and has been widely used for this purpose. More recently 1-(2-trifluoromethyl- phenyl) imidazole has been identified as a competitive inhibitor of nNOS and iNOS. (Moore and Handy, 1997). The truly selective nNOS inhibitor is still eagerly awaited.

Interestingly the induction of iNOS, but not the expressed enzyme cNOS, can be inhibited by glucocorticoids and this may be an explanation for the anti - inflammatory effects of such drugs (Moncada and Palmer, 1991).

From the foregoing account it is clear that the rat brain regions exhibit cNOS activity and it is $\mathrm{Ca}^{2+}$ and CaM-dependent enzyme and can be inhibited by L-arginine analogues. With the aim of understanding the in vivo effect of sub-lethal and lethal doses of chlordecone on the NOS activity of rat brain regions, this part of work was attempted by the author and the experimental data obtained was presented in table- 1 and (fig. 1). The results showed that both the doses of chlordecone like sub-lethal and lethal ones inhibited the NOS activity of all brain regions selected for the present investigation and the changes were found to be statistically significant over the control $(\mathrm{P}<0.001)$. In control group of rat brain areas the NOS activity was more for cerebellum and was followed by hypothalamus > mid brain > striatum > hippocampus > cerebral cortex > medulla oblongata. The tissue specific trends obtained were in agreement with the sequence as cited by Stuehr (1992). The studies of Vincent and Kimura (1992) also showed existence of NOS machinery invarious parts of rat brain.

The reports of Desaiah and Koch (1975); Fariss et al., (1980); Desaiah (1980\& 1981); Jordan et al., (1981); Guzelian (1982); Bansal and Desaiah (1982a), Kodavanti et al., (1993); Mehendale (1995); showed inhibition of ATPase activity by various doses of chlordecone. Since ATPase is one of the CaM-dependent enzymes, from the reports of the above authors it may be stated that chlordecone interacts with CaM-mediated 
events. However there are direct reports where different OI interacts with CaM-dependent events. The Pala et al., (1991) have studied the in vitro effects of OP compounds such as malathion, methyl parathion and ethyl parathion on CaM activity of rat brain. These studies demonstrated that all the above stated OP compounds significantly effected complex formation between the dansyl $\mathrm{CaM}$ and phosphodiesterase. The same authors reported that $\mathrm{OP}$ compounds may interact with brain $\mathrm{CaM}$, altering its active conformation, and thus inhibit its biological activity. In addition Rajeswara Rao et al., (1999) have demonstrated that OI like malathion, carbanyl including chlordecone inhibit rat brain cNOS activity. As they have reported, $\mathrm{CaM}$ is a low molecular weight, $\mathrm{Ca}^{2+}$ binding protein that is found in high concentrations in the mammalian brain. The $\mathrm{Ca}^{2+}$-induced conformational change in $\mathrm{CaM}$ exposes the hydrophobic groups, which are binding sites for the largest enzyme. $\mathrm{CaM}$ antagonists, such as phenothiazenes and napthalene sulfonamide directly interact with hydrophobic groups of $\mathrm{CaM}$ and block its biological activity. Like wise our previous studies also showed that OI like organochlorine or organophosphorous compounds owing to their lipophilic nature, bind to the hydrophobic region of $\mathrm{CaM}$ and thus impair $\mathrm{CaM}$-dependent enzyme activities like $\mathrm{Ca}^{2+}$-ATPase, phosphodiesterase (Kitamura et al., 1995; Bhaskar and Rao, 2000). Similar mechanisms may be responsible for inhibition of NOS activity of various brain regions by chlordecone in this study.

\section{REFERENCES}

[1] Anonymous . 1997. Pesticide sales in the U.S. totales $\$ 11.3$ billion in 1995. Pesticide \& Toxic Chemical News, 25 (46) : 18.

[2] Bansal, S.K. and Desaiah, D. 1982a. Chlordecone toxicity : Effect of with-drawal on ATPase inhibition. Fed. Proc., 41 : 1582.

[3] Bhaskar, L.V.K.S. and Rajeswara Rao, B.2000. Inhibition of rat brain nitric oxide synthase activity by phosalone in vitro. Bull. Pure. Appl. Sci., 19A (2) : 117-119.

[4] Bredt, D.S. and Snyder, S.H. 1989. Nitric oxide mediates glutamate - linked enhancement of cGMP levels in the cerebellum. Proc. Natl. Acad. Sci., USA. 86 : 9030-9033.

[5] Bredt, D.S. and Snyder, S.H. 1990. Isolation of nitric oxide synthatase, a calmodulin - requiring enzyme: Proc. Natl. Acad. Sci.,USA, $87: 682$ - 685.

[6] Chighizola, C. and Meroni, P. L. 2012. The role of environmental estrogens and autoimmunity. Autoimmunity - Reviews - Elsevier

[7] Connor, J.C.O., Frame, S.R and Ladics, G.S 2002. Evaluation of a 15-day screening assay using intact male rats for identifying antiandrogens. SOC. Toxicology.

[8] Desaiah, D. and Koch, R.B. 1975. Inhibition of ATPase activity in channel catfish by kepone its reduction product. Bull. Environ. Contam. Toxicol., 13 : 153-158.

[9] Desaiah, D. 1980. Comparative effects of chlordecone and mirex on rat cardiac ATPases and binding of ${ }^{3} \mathrm{H}-\mathrm{catecholamines.} J$. Environ. Pathol. Toxicol., $4: 237-248$.

[10] Desaiah, D. 1981. Interaction of chlordecone with biological membranes. J. Toxicol. Env. Hlth., 8 : 719-730.

[11] Fariss, M.W., Blanke, R.V., Saady, J.J. and Guzelian, P.S. 1980. Demonstration of major metabolic pathways for chlordecone (kepone) in humans. Drug.Metab.Dispos., $8: 434-438$.

[12] Forstermann, U., Gorsky, L.D., Pollock, J.S., Ishii, K., Schmidt, H.H.H.W., Heller,M. and Murad, F. 1990. Hormone-induced biosynthesis of endothelium - derived relaxing factor/nitric oxide - like material in NIE - 115 neuroblastoma cells requires calcium and calmodulin. Mol. Pharmacol., $38: 1-7$.

[13] Garvey, E.P., Oplinger, J.A., Furfine, E.S., Kiff, R.J., Laszlo, F., Whittle, B.J. and Knowles, R.G. $1997.1400 W$ is a slow, tight binding, and highly selective inhibitor of inducible nitric-oxide synthase in vitro and in vivo. J. Biol. Chem., $272: 4959$.

[14] Griffiths, C., Bon, C. and Garthwaite, J. 1998. Nitric oxide in CNS physiology and pathology. Neurotransmission, 14 : 3.

[15] Guzelian, P.S. 1982. Comparative toxicology of chlordecone (Kepone) in humans and experimental animals. Ann. Rev. Pharmacol. Toxicol., 22: 89-113.

[16] Jaffrey, S.R. and Snyder, S.H. 1996. PIN : An associated protein inhibitor of neuronal nitric oxide synthase. Science, 274 : 274.

[17] Jordan, J.E., Grice, T., Mishra, S.K. and Desaiah, D. 1981. Acute chlordecone toxicity in rats: A relationship between tremor and ATPase activities. Neurotoxicology, $2: 355-365$.

[18] Kitamura, Y., Arima, T., Imaizumi, R., Sato, T. and Nomura, Y. 1995. Inhibition of constitutive nitric oxide synthase in the brain by pentamidine, a calmodulin antagonist. European. J. Pharmacol. Mol. Pharmacol., Section 19 (2) : 299-304.

[19] Klatt, P., Schmidt, K., Brunnerr, F. and Mayer, B. 1994. Inhibitors of brain nitric oxide synthase. Binding kinetics, metabolism, and enzyme inactivation. J. Biol.Chem., $269: 1674$.

[20] Kodavanti, P.R.S., Rao, V.C. and Mehendale, H. M. 1993. Loss of calcium homeostasis leads to progressive phase of chlordecone potentiated carbon tetrachloride hepatotoxicity. Toxicol. Appl. Pharmacol., 122: 77-87.

[21] Kolanczyk, R., Mc Ardle, C and Mekenyan. O 2008. The use of metabolising systems for in vitro testing of endocrina disruptors. Ingentaconnect. Com.

[22] Mc Dougall, J. 1994. Guarded optimism in agrochemicals. Chem. \& Ind., 7: 264.

[23] Mehendale, H. M. 1995. Toxicodynamics of low level toxicant interactions of biological significance: Inhibition of tissue repair. Toxicolgy, 105: 251-266.

[24] Moncada, S. and Palmer, R.M.J. 1991. Inhibition of inducible nitric oxide synthase by glucocorticoids: Yet another explanation for their anti-inflammatory effects? TIPS, 12 : 130.

[25] Moore, P.K. and Handy, R.L. 1997. Selective inhibitors of neuronal nitric oxide synthase - is no NOS really good NOS for the nervous system? TIPS, $18: 204$.

[26] Oberg, M., Westerholm, E., Fattore, E., Stern, N and Hanberg. A 2010. Toxicity of Bromkal 70-5 DE, A technical mixture of polybrominated diphenyl ethers, following $28 \mathrm{~d}$ of oral exposure in rats and impact of analysed impurities. Elsevier.

[27] Pala, I., Vig, P.J.S., Desaiah, D. and Srinivasan, A. 1991. In vitro effects of organophosphorous compounds on calmodulin activity. J.Appl. Toxicol., 11(6) : 391-395.

[28] Patisaul, H.B 2013. Effects of Environmental endocrime disruptors and phytoestrogens on the kisspeptin system.

[29] Rajeswara Rao, M., Vijaya, P., Kanji, K. and Sekhar, V. 1999. Pesticide induced changes of nitric oxide synthase in rat brain in vitro. Drug and Chem. Toxicol., 22(2) : 411-420.

[30] Rautio, A., Hakkola, J. And pelkonen. P. 2012 Metabolism of pesticides by human cytochrome P450 enzymes in Vitro-a survey. Integrated pest. Intechopen. Com. 
[31] Salter, M., Richard, G. K. and Moncada, S. 1991. Widespread tissue distribution, species distribution and changes in activity of $\mathrm{Ca}^{2+}$ - dependent and $\mathrm{Ca}^{2+}$ - independent nitric oxide synthases. FEBS, 291 (1) : 145-149.

[32] Stuehr, D. J. 1992. Mammalian nitric oxide sythases. Advances in enzymology, pp. 287 - 346

[33] Vincent, S.R. and Kimura, H. 1992. Histochemical mapping of nitric oxide synthase in the rat brain. Neurosci., 46(4) : 755-784

[34] Waibel, H. 1994. Global pesticide markets and future prospects for pesticides. Working paper, 16th Session FAO/UNEP Pannel of Experts on IPM, Rome, 25-29, April; 15.

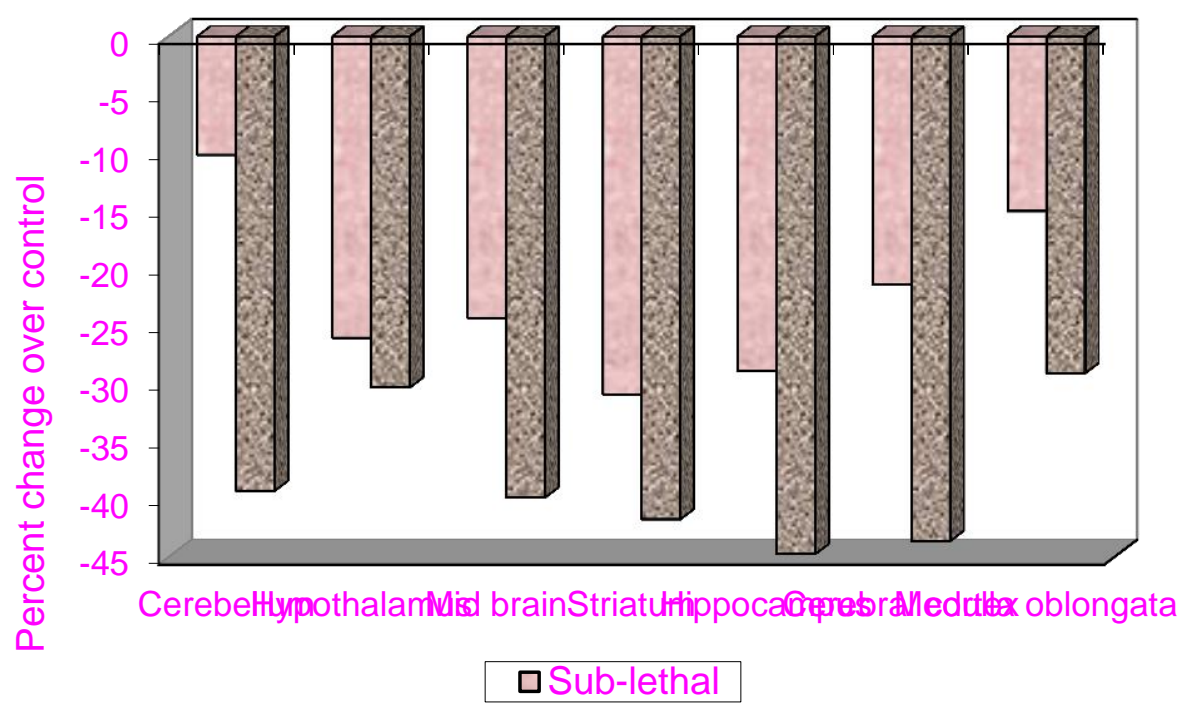

